\title{
PENENTUAN JALUR DISTRIBUSI DENGAN METODE SAVING MATRIKS
}

\author{
Fandi Ahmad', Hafidz Fadel Muharram² \\ Universitas Islam Jakarta \\ Jl. Balai Rakyat Utan Kayu Matraman Jak-Tim 13120 \\ Teknik industri, \\ Ahmad_fandi@rocketmail.com
}

\begin{abstract}
ABSTRAK
Dalam persaingan bisnis yang makin ketat dibutuhkan strategi dalam menetukan optimalisasi dan efesiensi, mengefektifkan jalur distribusi barang akan berakibat pada profit yang diperoleh perusahaan dan harga barang yang makin kompetitif, kesalahan penentuan jalur distribusi ke customer akan mengakibatkan jalur pengiriman yang ditempuh terlalu panjang dan rumit sehingga mengakibatkan biaya transportasi yang mahal. Dengan adanya permasalahan tersebut, maka perlu dilakukan penentuan rute yang akan dilalui sehingga dapat meminimalkan biaya transportasi pada Metode Saving Matrix dipilih dalam penelitian ini untuk menentukan rute distribusi produk $t$ agar diperoleh rute dan memperoleh biaya transportasi yang optimal.

Dari hasil penelitian rute pada penelitian ini diketahui berjumlah 18 rute dari sebelumnya berjumlah 25 rute, sehingga diperoleh pernghematan 7 rute, total jarak melalui metode perhitungan saving matrix, nearest insert dan nearest neighbour adalah sebesar 1700,69 km. Sedangkan total jarak pengiriman rute aktual pada perusahaan adalah sebesar 2046,97 km. Penghematan antara rute penelitian ini dengan rute aktual perusahaan adalah sebesar 346,28 $\mathrm{km}$.sedangkan daris sisi total biaya pengiriman/transportasi yang dihasilkan melalui metode perhitungan saving matrix, nearest insert dan nearest neighbour adalah sebesar Rp. 483.927.812. Dari sisi biaya pengiriman/transportasi rute aktual pada perusahaan adalah sebesar Rp. 629.281.041. Penghematan dengan metode penelitian saving matrix adalah sebesar Rp. 145.353.229 atau 23,09\%
\end{abstract}

Kata kunci: Transportasi, Saving matriks, Optimalisasi

\begin{abstract}
In the increasingly fierce business competition strategies are needed to determine optimization and efficiency, streamlining the distribution channels of goods will result in profits obtained by the company and increasingly competitive goods prices, errors in determining the distribution path to the customer will lead to too long and complicated shipping lines resulting expensive transportation costs. With these problems, it is necessary to determine the route to be passed so as to minimize transportation costs in the Saving Matrix Method selected in this study to determine the product distribution route to obtain the route and obtain optimal transportation costs.

From the results of the route research in this study it is known that there are 18 routes from the previous number of 25 routes, so obtained savings of 7 routes, the total distance through the calculation method of saving matrix, nearest insert and nearest neighbor is equal to 1700.69 $\mathrm{km}$. While the total distance of shipping the actual route to the company is $2046.97 \mathrm{~km}$. Savings between the route of this research with the actual route of the company is $346.28 \mathrm{~km}$. While
\end{abstract}


from the total side of the shipping / transportation costs generated through the calculation method of saving matrix, nearest insert and nearest neighbor is Rp. 483,927,812. In terms of shipping / transportation costs the actual route of the company is Rp. 629,281,041. Savings with the saving matrix research method is $R p .145,353,229$ or $23.09 \%$

\section{Keywords: Transportation, Saving matrix, Optimization.}

\section{PENDAHULUAN \\ 1.1 Latar Belakang}

PT. Natamas Plast merupakan sebuah pabrik yang meproduksi juga mendistribusikan berbagai macam produk. Sasaran distribusi PT. Natamas Plast adalah dapat melakukan waktu pengiriman produk secara tepat, biaya yang efisien, dan pelayanan yang baik. PT. Natamas Plast dituntut untuk dapat merancang kinerja pengiriman yang reliabel. Namun dalam kenyataannnya ada beberapa keterbatasan atau permasalahan dari perusahaan, dengan proses distribusi dalam satu kali pengiriman produk hanya dilakukan pada satu customer, sehingga kurang adanya perencanaan pengiriman dan pendistribusian barang yang tepat untuk menentukan jalur distribusi ke customer yang mengakibatkan jalur pengiriman yang ditempuh sehingga mengakibatkan biaya transportasi yang mahal. Dengan adanya permasalahan tersebut, dapat dilihat biaya transportasi masih sangat tinggi maka perlu dilakukan penentuan rute yang akan dilalui sehingga dapat meminimalkan biaya transportasi pada PT. Natamas Plast.

Metode Saving Matrix dapat digunakan untuk menentukan rute distribusi produk ke customer dengan cara menentukan urutan rute distribusi yang harus dilalui dan jumlah alat angkut berdasarkan kapasitas dari alat angkut tersebut. Metode ini diterapkan agar diperoleh rute terpendek dan memperoleh biaya transportasi yang optimum.

Mengingat bahwa untuk mengurangi suatu biaya transportasi pengiriman barang dalam rangka meningkatkan efektifitas supply chain untuk memenuhi kebutuhan pelanggan, maka diperlukan suatu perencanaan yang baik oleh perusahaan. Selain itu juga diperlukan perencanaan yang baik pula dalam menentukan rute pengiriman dari suatu armada pengiriman dalam supply chain, berdasarkan jarak dari gudang ke customer. Maka dari itu penulis akan mengemukakan permasalahan tentang bagaimana menentukan rute distribusi dari perusahaan kepada customer dengan menggunakan metode saving matrix untuk meminimalisasi biaya transportasi. Kinerja sistem transportasi memegang peranan penting dalam pelayanan kepada pelanggan karena harus

menjamin mobilitas produk di antara berbagai simpul sistem dengan efisiensi tinggi dan ketepatan waktu serta pada saat yang sama harus dapat mengurangi biaya transportasi (Purnomo 2010)

\subsection{Tinjauan Pustaka}

Produsen menggunakan saluran distribusi untuk melakukan proses penyaluran barang sampai ke konsumen akhir atau pemakai industri (Swastha dan Bashu, 2007). Secara garis besar, pendistribusian dapat diartikan sebagai kegiatan pemasaran yang berusaha memperlancar dan mempermudah penyampaian barang dan jasa dari produsen kepada konsumen, sehingga penggunaanya sesuai dengan keperluan yang dibutuhkan (Tjiptono dan Fandy, 2008). Menurut Soo Wook Kim (2006) manajemen distribusi dan transportasi dapat disebut juga sebagai manajemen logistik atau distribusi fisik. Logistik modern dapat didefenisikan sebagai proses pengelolaan yang strategis terhadap pemindahan dan penyimpanan barang, suku cadang dan barang jadi dari para supplier, diantara fasilitas perusahaan dan kepada para pelanggan. Kegiatan transportasi dan distribusi bisa dilakukan oleh perusahaan manufaktur dengan 
membentuk bagian distribusi / transportasi tersendiri atau diserahkan kepada pihak ketiga. Menurut Pujawan (2007) Metode Saving Matrix merupakan salah satu teknik yang digunakan untuk menjadwalkan sejumlah kendaraan terbatas untuk mengirimkan barang produksinya ke konsumen dengan meminimumkan jarak tempuh. Langkah-langkah yang dilakukan yaitu:

1. Mengidentifikasi matrik jarak. Langkah awal metode ini adalah mencatat jarak antara gudang ke masing - masing lokasi pelanggan dan jarak antar lokasi. Dengan mengetahui koordinat dari masing - masing lokasi, maka jarak antar dua lokasi dapat dihitung dengan menggunakan rumus standar. Misalkan dua lokasi diketahui koorinat $(\mathrm{x} 1, \mathrm{y} 1)$ dan $(\mathrm{x} 2, \mathrm{y} 2)$, maka dapat dihitung jarak antara dua lokasi tersebut dengan rumus:

$$
J(1,2)=\sqrt{\left(x_{1}-x_{2}\right)^{2}+\left(y_{1}-y_{2}\right)^{2}}
$$

2. Selanjutnya dalam Mengidentifikasi matriks penghematan. Pada awal langkah ini diasumsikan bahwa setiap toko akan dikunjungi oleh satu truk secara eksklusif. Maka akan ada penghematan yang akan diperoleh jika dua atau lebih rute bila digabungkan menjadi satu rute. Savings matrix merepresentasikan penghematan yang bisa direalisasikan dengan menggabungkan dua toko maupun pelanggan ke dalam satu rute.Apabila masing-masing toko 1 dan toko 2 dikunjungi secara terpisah maka jarak yang dilalui adalah jarak dari gudang ke toko 1 dan dari toko 1 balik ke gudang. ditambah dengan jarak dari gudang ke toko 2 dan kemudian balik ke gudang.
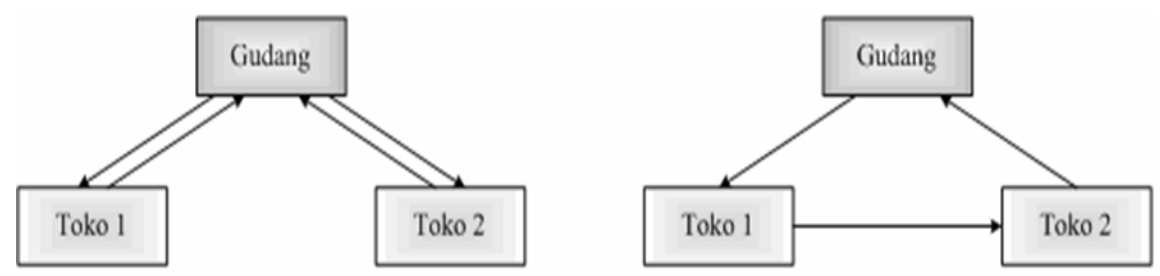

*Sumber: Supply Chain Management, I Nyoman Pujawan

\section{Gambar 2.1 Perubahan yang Terjadi Dengan Mengkonsolidasikan Toko 1 dan Toko 2 ke Dalam Satu Rute}

Melalui Gambar 2.1 dapat dilihat bahwa perubahan jarak (penghematan) adalah sebesar total jarak kiri dikurangi total jarak kanan yang besarnya adalah: $2 \mathbf{J}(\mathrm{G}, 1)+2 \mathrm{~J}(\mathrm{G}, 2)-[\mathrm{J}$ $(\mathrm{G}, 1)+\mathbf{J}(1,2)+\mathbf{J}(2, \mathrm{G})]=\mathbf{J}(\mathrm{G}, 1)+\mathbf{J}(\mathrm{G}, 2)-\mathbf{J}(1,2)$, Hasil ini diperoleh dengan asumsi bahwa jarak $(\mathrm{x}, \mathrm{y})$ sama dengan jarak $(\mathrm{y}, \mathrm{x})$.Hasil di atas bisa digeneralisasikan dengan cara: $S(x, y)=J(G, x)+J(G, y)-J(x, y)$, Dimana $S(x, y)$ adalah penghematan jarak (savings) yang diperoleh dengan menggabungkan rute $\mathrm{x}$ dan $\mathrm{y}$ menjadi satu. Dengan menggunakan formula tersebut maka matriks penghematan jarak bisa dihitung untuk semua toko dan hasilnya dapat dibuat dalam suatu tabel matriks penghematan jarak.

3. Kemudian selanjutnya mengalokasikan toko ke kendaraan atau rute. Dengan berbekal tabel penghematan, dapat dilakukan alokasi toko ke kendaraan atau rute. Toko-toko yang digabungkan ke dalam satu rute pengiriman akan layak digabungkan sampai pada batas kapasitas truk yang ada. Penggabungan akan dimulai dari nilai penghematan terbesar karena diupayakan untuk memaksimumkan penghematan.dan mengurutkan toko (tujuan) 
dalam rute yang sudah terdefinisi. Setelah alokasi toko ke rute dilakukan, langkah berikutnya adalah menentukan urutan kunjungan.

Terdapat beberapa metode yang dapat digunakan untuk menentukan urutan kunjungan tersebut, diantaranya adalah metode nearest insert dan metode nearest neighbor. Pada prinsipnya, tujuan dari pengurutan ini adalah untuk meminimumkan jarak perjalanan truk. Metode nearest insert menggunakan prinsip memilih toko yang apabila dimasukkan ke dalam rute yang sudah ada menghasilkan tambahan jarak yang minimum. Sedangkan metode nearest neighbor memiliki prinsip dengan menambahkan toko yang jaraknya paling dekat dengan toko yang telah dikunjungi terakhir.

Tujuan dari manajemen supply chain adalah untuk menjamin kesatuan gerak dari jumlah dan kualitas yang memadai pada persediaan yang meliputi banyak hal seperti perencanaan dan komunikasi. Lebih sederhana lagi dapat diartikan bahwa tujuan dari manajemen supply chain adalah untuk memastikan seluruh item barang berada pada tempat dan waktu yang tepat agar dapat memberikan keuntungan yang terbaik bagi perusahaan dan konsumen.

Logistik merupakan rangkaian kegiatan pengambilan dan penempatan barang dari tempat dan waktu yang telah direncanakan. Pengertian logistik lain adalah sekumpulan aktivitas fungsional (transportasi, pengendalian inventori, dan lain sebagainya) yang dilakukan sebuah perusahaan dalam proses mengubah bahan baku menjadi produk jadi. Secara umum kegiatan logistik terdiri dari dua kegiatan yaitu kegiatan pergerakan (move) yang bersifat dinamis dan keinginan penyimpanan (store) yang bersifat statis.

\section{METODE PENELITIAN}

Penelitian dilakukan di PT. Natamas Plast yang melakukan kegiatan distribusi serta produksi manufaktrur industri kemasan plastik yang lebih mengkhususkan diri pada produksi pembuatan dan sekaligus penjualan kemasan plastik untuk farmasi dan kosmetik yang berada diwilayah Jabodetabek. Penelitian dilakukan selama 3 bulan dimulai bulan Januari sampai Maret 2018 dan untuk mendapatkan data yang dibutuhkan untuk penentuan jalur distribusi yang baik dan mengoptimalkan biaya transportasi di PT. Natamas Plast. Metode pengumpulan data yang dilakukan yaitu Interview, kemudian melakukan peninjauan atau pengamatan langsung ke lapangan dengan melakukan pengambilan data pada perusahaan terkait. Data yang diambil merupakan data historis perusahaan yang berhubungan dengan jumlah pengiriman, jumlah customer, jumlah kendaraan. Selain itu, wawancara dengan pihak terkait juga dilakukan untuk pemahaman lebih lanjut mengenai permasalahan yang ada dan melakukan penyusunan data historis yang didapat akan dipresentasikan dalam bentuk diagram dan pemetaan seluruh elemen sistem terkait pada proses produksi disertai waktu dan data aktual. Dan tahapan akhir adalah kesimpulan dari keseluruhan penelitian yang telah dilakukan dan saran untuk pengembangan penelitian di kemudian hari.

\section{HASIL DAN PEMBAHASAN}

Data jumlah distributor beserta alamat lengkap dan kordinat pada peta PT. Natamas Plast didapat melalui aplikasi Google Maps adalah sebagai berikut: 
TABEL 4.1 Data Alamat Pelanggan Beserta Koordinat

\begin{tabular}{|c|c|c|c|c|}
\hline No & Kode - Nama Toko & Alamat & Longitude & Longitude \\
\hline 0 & $\begin{array}{l}100 \text { - PT Natamas } \\
\text { Plast }\end{array}$ & $\begin{array}{l}\text { J1. Raya Kedep No. 69, Cicadas, } \\
\text { Gn. Putri, Bogor }\end{array}$ & -6.446 & 106,922 \\
\hline 1 & $\begin{array}{l}101-\text { PT Simba } \\
\text { Indosnack Makmur }\end{array}$ & $\begin{array}{l}\text { Jl. Pancasila IV, Cicadas, Gn. Putri, } \\
\text { Bogor }\end{array}$ & -6.437 & 106.927 \\
\hline 2 & $\begin{array}{l}102-\text { PT Blessing } \\
\text { Indonesia Jaya }\end{array}$ & $\begin{array}{l}\text { Jl. Pancasila V, No 48, Cicadas, } \\
\text { Gunung Putri, Bojong Nangka, } \\
\text { Bogor }\end{array}$ & -6.442 & 106.896 \\
\hline 3 & $\begin{array}{l}103 \text { - PT Akasha } \\
\text { Wira International }\end{array}$ & $\begin{array}{l}\text { Jl. Raya Mayor Oking Jaya } \\
\text { Atmajaya, Ciriung, Cibinong, } \\
\text { Bogor }\end{array}$ & -6.472 & 106.862 \\
\hline 4 & $\begin{array}{l}104 \text { - PT Immortal } \\
\text { Cosmedika } \\
\text { Indonesia }\end{array}$ & $\begin{array}{l}\text { J1. Pekapuran No 32, Sukatani, } \\
\text { Tapos, Depok, Jawa Barat }\end{array}$ & -6.387 & 106.875 \\
\hline 5 & $\begin{array}{lll}105- & \text { PT } & \text { Ristra } \\
\text { Indolab } & & \\
\end{array}$ & $\begin{array}{l}\text { J1. Lambau Sanja, Citereup, } \\
\text { Kampung Lio Baru, Bogor }\end{array}$ & -6.501 & 106.862 \\
\hline 6 & $\begin{array}{l}106 \text { - PT Trakindo } \\
\text { Utama }\end{array}$ & $\begin{array}{l}\text { J1. Raya Narogong No. 32, Limus } \\
\text { Nunggal, Cileungsi, Bogor }\end{array}$ & -6.383 & 106.968 \\
\hline 7 & $\begin{array}{l}107 \text { - PT Cisarua } \\
\text { Mountain Dairy }\end{array}$ & $\begin{array}{l}\text { Jl. Lanbau No 2, Sentul, Babakan } \\
\text { Madang, Bogor }\end{array}$ & -6.515 & 106.851 \\
\hline 8 & $\begin{array}{l}108 \text { - PT Star Abadi } \\
\text { Ratu Indonesia }\end{array}$ & $\begin{array}{l}\text { Jl. Serpong Parung No. 39-83, } \\
\text { Curug, Gn. Sindur, Bogor }\end{array}$ & -6.406 & 106.722 \\
\hline 9 & $\begin{array}{l}109-\text { PT Gloria } \\
\text { Origita Cosmetics }\end{array}$ & $\begin{array}{l}\text { Jl. Padrenana No. 35, Padurenan, } \\
\text { Gn. Sindur, Bogor }\end{array}$ & -6.389 & 106.709 \\
\hline 10 & 110 - PT L'Essentials & $\begin{array}{l}\text { Taman Tekno BSD, Sektor } 11 \\
\text { Block C No 3A, Setu, Tangerang } \\
\text { Selatan }\end{array}$ & -6.337 & 106.674 \\
\hline 11 & $\begin{array}{l}111-\mathrm{PT} \text { Mandom } \\
\text { Indonesia tbk. }\end{array}$ & $\begin{array}{l}\text { Jl. Jawa, MM2100 Cibitung } \\
\text { Industrial Estate, Gandamekar, } \\
\text { Cikarang, Bekasi }\end{array}$ & -6.298 & 107.082 \\
\hline 12 & $\begin{array}{l}112 \text { - PT Genero } \\
\text { Phamaceuticals }\end{array}$ & $\begin{array}{l}\text { Kawasan Industri Jababeka 2, Jl. } \\
\text { Industri Selatan 1, Pasirsari, } \\
\text { Cikarang, Bekasi }\end{array}$ & -6.307 & 107.162 \\
\hline 13 & $\begin{array}{l}113 \text { - PT Windsor } \\
\text { Indonesia }\end{array}$ & $\begin{array}{l}\text { Jl. Duren Tiga No. 101, Duren Tiga, } \\
\text { Jakarta Selatan }\end{array}$ & -6.254 & 106.834 \\
\hline 14 & $\begin{array}{l}114 \text { - Senopati Skin } \\
\text { Centre }\end{array}$ & $\begin{array}{l}\text { Jl. Senopati No. 44, Senayan, } \\
\text { Kebayoran Baru, Jakarta Selatan }\end{array}$ & -6.229 & 106.804 \\
\hline 15 & $\begin{array}{l}115 \text { - PT Graha } \\
\text { Farma }\end{array}$ & $\begin{array}{l}\text { Jl. Tegal Rotan Jaya No. 10, Pd. } \\
\text { Jaya, Pd. Aren, Tangerang Selatan, } \\
\text { Banten }\end{array}$ & -6.281 & 106.723 \\
\hline 16 & $\begin{array}{l}116 \text { - PT Bina Karya } \\
\text { Prima }\end{array}$ & $\begin{array}{l}\text { Jl. Raya Bekasi Km, } 27 \text { Pejuang } \\
\text { Medan Satria, Kaliabang Tengah } \\
\text { Bekasi Utara }\end{array}$ & -6.198 & 106.993 \\
\hline 17 & $\begin{array}{l}117 \text { - PT Cosmopack } \\
\text { Plastindo Utama }\end{array}$ & $\begin{array}{l}\text { Jl. Kaliabang Raya No. 1A, Pondok } \\
\text { Ungu, Medan Satria, Bekasi }\end{array}$ & -6.196 & 106.976 \\
\hline
\end{tabular}




\begin{tabular}{|c|c|c|c|c|}
\hline No & Kode - Nama Toko & Alamat & Longitude & Longitude \\
\hline 18 & $\begin{array}{l}118 \text { - PT Martina } \\
\text { Berto }\end{array}$ & $\begin{array}{l}\text { J1. Puloayang Raya, Kawasan } \\
\text { Industri Pulogadung, Cakung, } \\
\text { Jakarta Timur }\end{array}$ & -6.205 & 106.912 \\
\hline 19 & $\begin{array}{l}119-\text { PT Morel } \\
\text { Renee }\end{array}$ & $\begin{array}{l}\text { J1. Rawagatel, Kws. } \\
\text { Industri } \\
\text { Pulogadung R.2-2A, } \\
\text { Jatinegara, Jaktim }\end{array}$ & -6.203 & 106.911 \\
\hline 20 & $\begin{array}{ll}120 \quad- & \text { PT } \\
\text { Gondowangi } & \\
\text { Tradisional K. } & \end{array}$ & $\begin{array}{l}\text { Jl. Pemuda No 713, Jati, Pulo } \\
\text { Gadung, Jakarta Timur }\end{array}$ & -6.193 & 106.896 \\
\hline 21 & 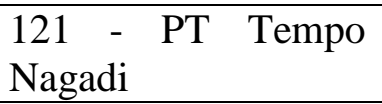 & $\begin{array}{l}\text { J1. Pulokambing Raya Block 2E No. } \\
\text { 7, Terate, Cakung, Jakarta Timur }\end{array}$ & -6.191 & 106.911 \\
\hline 22 & 122 - PT Lion Wings & $\begin{array}{l}\text { Jl. Inspeksi Cakung Drain Tim No. } \\
\text { 1, Cakung, Jakarta Timur }\end{array}$ & -6.174 & 106.931 \\
\hline 23 & $\begin{array}{l}123 \text { - PT Sakafarma } \\
\text { Laboratories }\end{array}$ & $\begin{array}{l}\text { Jl. Jend. A. Yani No. 2, Pulo Mas, } \\
\text { Kayu Putih, Pulogadung, Jakarta } \\
\text { Timur }\end{array}$ & -6.173 & 106.877 \\
\hline 24 & $\begin{array}{l}124 \text { - Berkat Jaya } \\
\text { Plastik }\end{array}$ & $\begin{array}{l}\text { Jl. Pramuka Raya No. 9, } \\
\text { Palmeriam, Matraman, Jakarta } \\
\text { Timur }\end{array}$ & -6.197 & 106.587 \\
\hline 25 & $\begin{array}{l}125 \text { - PT. Nuansa } \\
\text { Wangi Sejati }\end{array}$ & $\begin{array}{l}\text { Jl. Raya } \begin{array}{c}\text { Duri } \\
\text { Cengkareng, Jakarta Barat }\end{array}\end{array}$ & -6.158 & 106.891 \\
\hline 26 & $\begin{array}{l}126 \text { - PT Universe } \\
\text { Lion }\end{array}$ & $\begin{array}{l}\text { J1. Pluit Raya No. 21, Penjaringan, } \\
\text { Jakarta Utara }\end{array}$ & -6.126 & 106.797 \\
\hline 27 & $\begin{array}{l}127 \text { - PT Promedic } \\
\text { Dyna Farma }\end{array}$ & $\begin{array}{l}\text { Jl. Tanjung } \begin{array}{l}\text { Pura } \\
\text { Pegadungan, } \\
\text { Barat }\end{array} \\
\text { Kalideres, Jakarta }\end{array}$ & -6.132 & 106.691 \\
\hline 28 & $\begin{array}{lll}128- & \text { PT } & \text { Yuasa } \\
\text { Battery } & & \\
\end{array}$ & $\begin{array}{l}\text { Jl. Mh. Thamrin, Panunggangan } \\
\text { Utara, Tangerang, Banten }\end{array}$ & -6.217 & 106.631 \\
\hline 29 & $\begin{array}{l}129 \text { - PT Sparindo } \\
\text { Mustika }\end{array}$ & $\begin{array}{l}\text { Ruko Mahkota Mas No. 52, Jl. Mh, } \\
\text { Thamrin, Cikokol, Tangerang, } \\
\text { Banten }\end{array}$ & -6.176 & 106.794 \\
\hline 30 & $\begin{array}{l}130 \text { - PT Indoyoso } \\
\text { Sumber Protein }\end{array}$ & $\begin{array}{l}\text { Jl. Raya No. 101, RT05/05, Sentul, } \\
\text { Babakan Madang, Bogor }\end{array}$ & -6.493 & 106.859 \\
\hline
\end{tabular}

*Sumber: PT. Natamas Plast

Data jumlah penjualan rata-rata dalam 3 bulan beserta volume permintaan per hari per toko adalah sebagai berikut:

Tabel 4.2 Data Penjualan dan Volume Permintaan

\begin{tabular}{|l|l|l|l|}
\hline No & Nama Toko & $\begin{array}{l}\text { Rata-rata Penjualan } \\
\text { per bulan (rp) }\end{array}$ & $\begin{array}{l}\text { Rata-rata } \\
\text { Volume } \\
\text { Permintaan } \\
\text { Per hari } \\
(\mathrm{m} 3)\end{array}$ \\
\hline
\end{tabular}




\begin{tabular}{|c|c|c|c|}
\hline 1 & $\begin{array}{l}\text { PT Simba Indosnack } \\
\text { Makmur }\end{array}$ & $\begin{array}{l}\mathrm{Rp} \\
407,370,298.00\end{array}$ & 6 \\
\hline 2 & $\begin{array}{l}\text { PT Blessing Indonesia } \\
\text { Jaya }\end{array}$ & $\begin{array}{l}\mathrm{Rp} \\
502,592,837.00\end{array}$ & 7 \\
\hline 3 & $\begin{array}{l}\text { PT Akasha Wira } \\
\text { International }\end{array}$ & $\begin{array}{l}\mathrm{Rp} \\
126,478,030.00\end{array}$ & 2 \\
\hline 4 & $\begin{array}{l}\text { PT Immortal Cosmedika } \\
\text { Indonesia }\end{array}$ & $\begin{array}{l}\mathrm{Rp} \\
1,089,307,487.00\end{array}$ & 16 \\
\hline 5 & PT Ristra Indolab & $\begin{array}{l}\mathrm{Rp} \\
462,887,920.00\end{array}$ & 7 \\
\hline 6 & PT Trakindo Utama & $\begin{array}{l}\mathrm{Rp} \\
376,414,207.00\end{array}$ & 5 \\
\hline 7 & $\begin{array}{l}\text { PT Cisarua Mountain } \\
\text { Dairy }\end{array}$ & $\begin{array}{l}\mathrm{Rp} \\
1,245,390,876.00\end{array}$ & 18 \\
\hline 8 & $\begin{array}{l}\text { PT Star Abadi Ratu } \\
\text { Indonesia }\end{array}$ & $\begin{array}{l}\mathrm{Rp} \\
175,283,910.00\end{array}$ & 3 \\
\hline 9 & $\begin{array}{l}\text { PT Gloria Origita } \\
\text { Cosmetics }\end{array}$ & $\begin{array}{l}\mathrm{Rp} \\
762,381,732.00\end{array}$ & 11 \\
\hline 10 & PT L'Essentials & $\begin{array}{l}\mathrm{Rp} \\
234,174,740.00\end{array}$ & 3 \\
\hline 11 & $\begin{array}{l}\text { PT Mandom Indonesia } \\
\text { tbk. }\end{array}$ & $\begin{array}{l}\mathrm{Rp} \\
1,994,672,834.00\end{array}$ & 29 \\
\hline 12 & $\begin{array}{ll}\text { PT } & \text { Genero } \\
\text { Phamaceuticals } & \\
\end{array}$ & $\begin{array}{l}\mathrm{Rp} \\
291,029,384.00\end{array}$ & 4 \\
\hline 13 & PT Windsor Indonesia & $\begin{array}{l}\mathrm{Rp} \\
584,331,761.00\end{array}$ & 9 \\
\hline 14 & Senopati Skin Centre & $\begin{array}{l}\mathrm{Rp} \\
390,665,482.00 \\
\end{array}$ & 6 \\
\hline 15 & PT Graha Farma & $\begin{array}{l}\mathrm{Rp} \\
112,837,615.00\end{array}$ & 2 \\
\hline 16 & PT Bina Karya Prima & $\begin{array}{l}\mathrm{Rp} \\
1,095,608,469.00\end{array}$ & 16 \\
\hline 17 & $\begin{array}{l}\text { PT Cosmopack Plastindo } \\
\text { Utama }\end{array}$ & $\begin{array}{l}\mathrm{Rp} \\
518,726,370.00\end{array}$ & 8 \\
\hline 18 & PT Martina Berto & $\begin{array}{l}\mathrm{Rp} \\
412,188,927.00\end{array}$ & 6 \\
\hline 19 & PT Morel Renee & $\begin{array}{l}\mathrm{Rp} \\
819,273,857.00\end{array}$ & 12 \\
\hline 20 & $\begin{array}{l}\text { PT } \quad \text { Gondowangi } \\
\text { Tradisional K. }\end{array}$ & $\begin{array}{l}\mathrm{Rp} \\
113,364,340.00\end{array}$ & 2 \\
\hline 21 & PT Tempo Nagadi & $\begin{array}{l}\mathrm{Rp} \\
853,749,756.00\end{array}$ & 13 \\
\hline 22 & PT Lion Wings & $\begin{array}{l}\mathrm{Rp} \\
118,945,920.00 \\
\end{array}$ & 2 \\
\hline 23 & $\begin{array}{ll}\text { PT } & \text { Sakafarma } \\
\text { Laboratories } & \\
\end{array}$ & $\begin{array}{l}\mathrm{Rp} \\
163,757,660.00\end{array}$ & 2 \\
\hline 24 & Berkat Jaya Plastik & $\begin{array}{l}\mathrm{Rp} \\
1,095,508,469.00\end{array}$ & 16 \\
\hline
\end{tabular}




\begin{tabular}{|l|l|l|l|}
\hline 25 & PT. Nuansa Wangi Sejati & $\begin{array}{l}\mathrm{Rp} \\
432,510,702.00\end{array}$ & 6 \\
\hline 26 & PT Universe Lion & $\begin{array}{l}\mathrm{Rp} \\
378,604,513.00\end{array}$ & 6 \\
\hline 27 & PT Promedic Dyna Farma & $\begin{array}{l}\mathrm{Rp} \\
486,105,600.00\end{array}$ & 7 \\
\hline 28 & PT Yuasa Battery & $\begin{array}{l}\mathrm{Rp} \\
1,142,876,918.00\end{array}$ & 17 \\
\hline 29 & PT Sparindo Mustika & $\begin{array}{l}\mathrm{Rp} \\
645,274,964.00\end{array}$ & 9 \\
\hline 30 & $\begin{array}{l}\text { PT Indoyoso Sumber } \\
\text { Protein }\end{array}$ & $\begin{array}{l}\mathrm{Rp} \\
213,234,545.00\end{array}$ & 3 \\
\hline
\end{tabular}

*Sumber: PT. Natamas Plas

Sedangkan untuk jumlah dan kapasitas alat angkut yang tersedia adalah sebagai berikut:

\section{Tabel 4.3 Data Kendaraan dan Kapasitas Angkut}

\begin{tabular}{|l|l|l|}
\hline $\begin{array}{l}\text { Jenis } \\
\text { Kendaraan }\end{array}$ & Kapasitas Angkut (m3) & Jumlah Unit \\
\hline $\begin{array}{l}\text { Mitsubishi } \\
\text { L300 }\end{array}$ & 20 & 4 \\
\hline $\begin{array}{l}\text { Mitsubishi } \\
\text { Fuso }\end{array}$ & 32 & 10 \\
\hline
\end{tabular}

*Sumber: PT. Natamas Plast

\subsection{Hasil Perhitungan Matriks Jarak}

Jarak antara gudang ke masing-masing konsumen dan jarak antar konsumen dapat dihitung dengan menggunakan rumus jarak standar sebagai berikut: Dist $(A, B)=\sqrt{ }\left(x^{A}-x^{B}\right)^{2}+$ $\left(\mathrm{y}^{\mathrm{A}}-\mathrm{y}^{\mathrm{B}}\right)$. Jarak riil bisa didapat melalui pengukuran manual pada aplikasi Google Maps. PT. Natamas Plast melakukan pengiriman barang ke distributor setiap hari sesuai dengan jadwal yang sudah ditentukan.dan untuk keberangkatan rute dilakukan pada pukul 08:30 sampai 16:30. Jam kerja untuk pengiriman adalah dari mulai pukul 08:00 sampai pukul 16:00 dengan waktu istirahat pukul 12:00 sampai pukul 12:45. Berikut ini adalah gambar kordinat toko-toko:

\section{Gambar 4.1 Koordinat Customer PT. Natamas Plast}




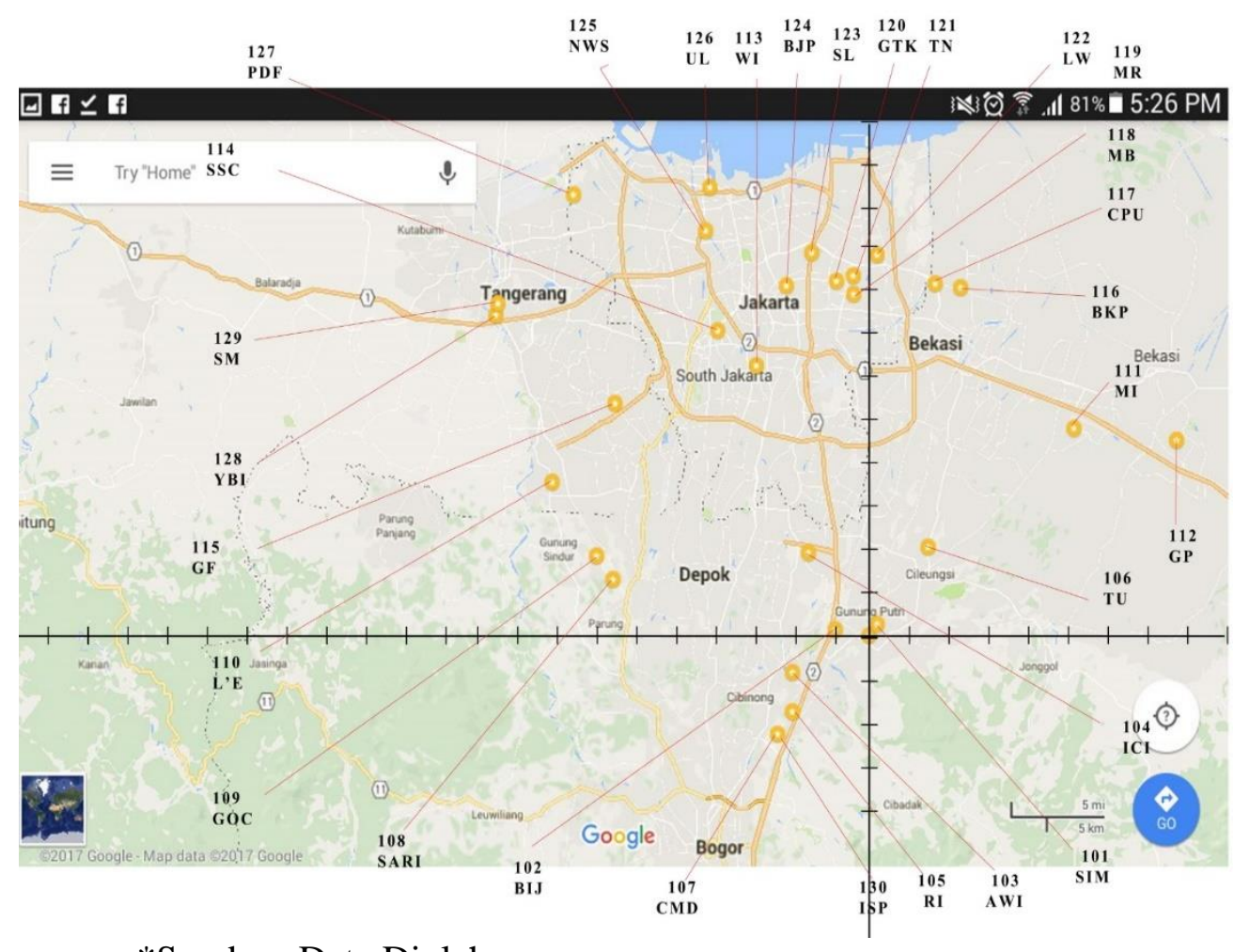

*Sumber: Data Diolah

Kemudian dari gambar tersebut di susun data koordinat dari setiap toko yang ada dan hasilnya adalah:

Tabel 4.4 Data koordinat PT. Natamas Plast dan Distributor

\begin{tabular}{|l|l|l|l|}
\hline NO & NAMA TOKO & \multicolumn{2}{l|}{ KOORDINAT } \\
\cline { 3 - 4 } & \multicolumn{1}{|l|}{ X } & Y \\
\hline 1 & PT Natamas Plast & 0 & 0 \\
\hline 2 & $\begin{array}{l}\text { PT Simba Indosnack } \\
\text { Makmur }\end{array}$ & 0 & 1 \\
\hline 3 & $\begin{array}{l}\text { PT Blessing Indonesia } \\
\text { Jaya }\end{array}$ & -1 & 0 \\
\hline 4 & $\begin{array}{l}\text { PT Akasha Wira } \\
\text { International Immortal }\end{array}$ & -2 & -1 \\
\hline 5 & $\begin{array}{l}\text { PT } \\
\text { Cosmedika Indonesia }\end{array}$ & 2 \\
\hline 6 & $\begin{array}{l}\text { PT Ristra Indolab } \\
\text { PT Trakindo Utama }\end{array}$ & -2 & -2 \\
\hline 7 & $\begin{array}{l}\text { PT Cisarua Mountain } \\
\text { Dairy }\end{array}$ & -3 & -2 \\
\hline 8 & $\begin{array}{l}\text { PT Star Abadi Ratu } \\
\text { Indonesia }\end{array}$ & -7 & 1 \\
\hline 9 & & \\
\hline
\end{tabular}




\begin{tabular}{|c|c|c|c|}
\hline 10 & $\begin{array}{l}\text { PT Gloria Origita } \\
\text { Cosmetics }\end{array}$ & -7 & 2 \\
\hline 11 & PT L'Essentials & -8 & 3 \\
\hline 12 & $\begin{array}{l}\text { PT Mandom Indonesia } \\
\text { tbk. }\end{array}$ & 5 & 5 \\
\hline 13 & $\begin{array}{ll}\text { PT } & \text { Genero } \\
\text { Phamaceuticals } & \end{array}$ & 8 & 4 \\
\hline 14 & PT Windsor Indonesia & -3 & 6 \\
\hline 15 & Senopati Skin Centre & -4 & 7 \\
\hline 16 & PT Graha Farma & -8 & 5 \\
\hline 17 & PT Bina Karya Prima & 3 & 8 \\
\hline 18 & $\begin{array}{l}\text { PT Cosmopack } \\
\text { Plastindo Utama }\end{array}$ & 2 & 8 \\
\hline 19 & PT Martina Berto & -1 & 8 \\
\hline 20 & PT Morel Renee & 0 & 8 \\
\hline 21 & $\begin{array}{l}\text { PT Gondowangi } \\
\text { Tradisional K. }\end{array}$ & -1 & 7 \\
\hline 22 & PT Tempo Nagadi & 0 & 7 \\
\hline 23 & PT Lion Wings & 0 & 9 \\
\hline 24 & $\begin{array}{l}\text { PT Sakafarma } \\
\text { Laboratories }\end{array}$ & -1 & 9 \\
\hline 25 & Berkat Jaya Plastik & -2 & 8 \\
\hline 26 & $\begin{array}{l}\text { PT. Nuansa Wangi } \\
\text { Sejati }\end{array}$ & -4 & 9 \\
\hline 27 & PT Universe Lion & -4 & 11 \\
\hline 28 & $\begin{array}{l}\text { PT Promedic Dyna } \\
\text { Farma }\end{array}$ & -7 & 10 \\
\hline 29 & PT Yuasa Battery & -9 & 7 \\
\hline 30 & PT Sparindo Mustika & -9 & 8 \\
\hline 31 & $\begin{array}{l}\text { PT Indoyoso Sumber } \\
\text { Protein }\end{array}$ & -3 & -3 \\
\hline
\end{tabular}

*Sumber: Data Diolah

Setelah diketahui koordinat dari masing - masing distributor dengan menggunakan skala 1:5.000.000 cm, maka jarak dari PT. Natamas Plast ke masing - masing distributor serta dari distributor ke distributor dapat diketahui dengan menggunakan rumus:

$\operatorname{Dist}(A, B)=\sqrt{ }\left(x^{A}-x^{B}\right)^{2}+\left(y^{A}-y^{B}\right)^{2}$

Sebagai contoh:

Dist $(\mathrm{PT}, \mathrm{Simba})=\sqrt{ }(0-0)^{2}+(0-1)^{2}=1.0$

$$
=1.0 * 5=5.0 \mathrm{~km}
$$




\section{Tabel 4.5 Hasil Identifikasi Matriks Jarak}

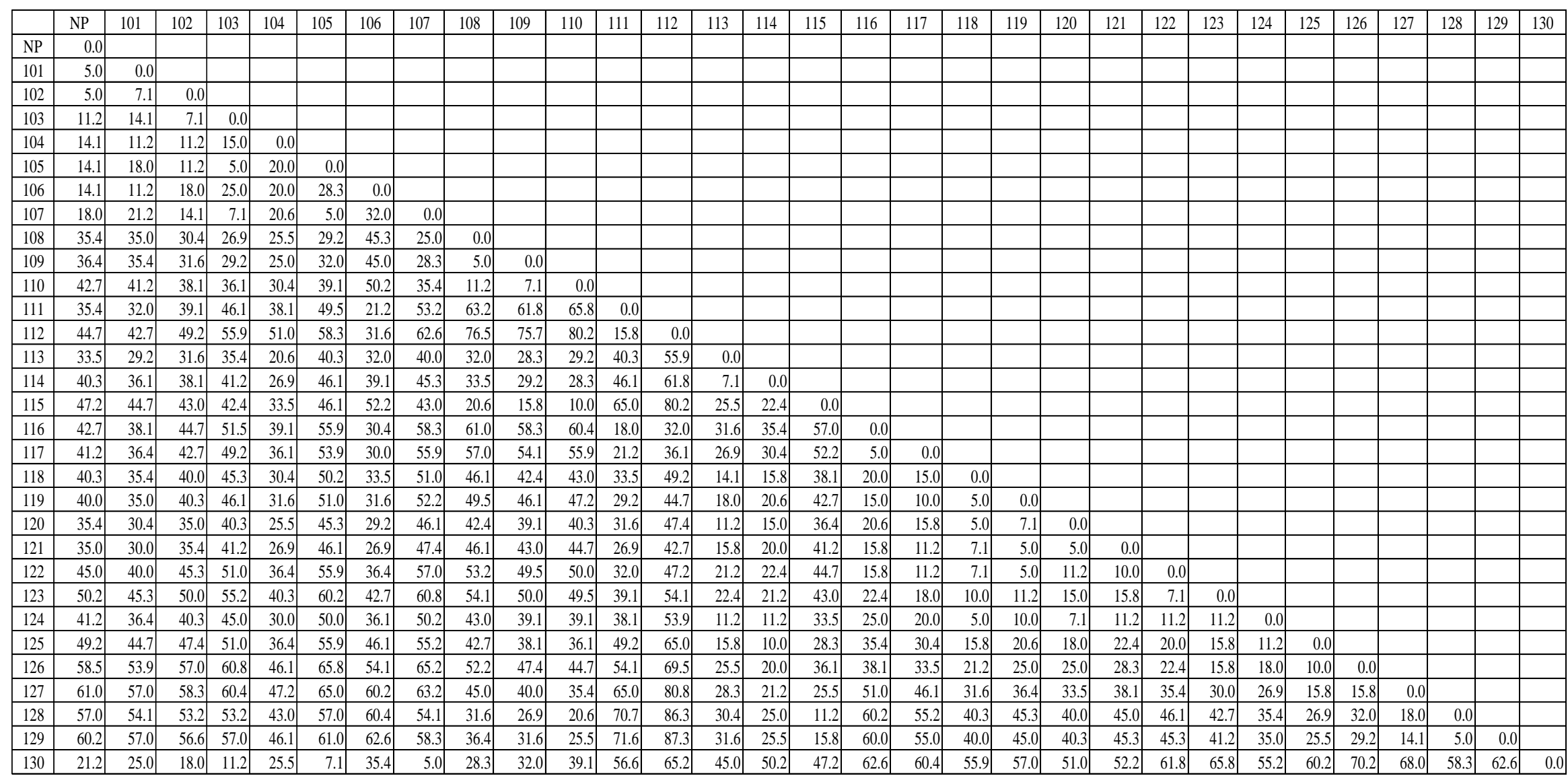

*Sumber: Data Diolah 


\subsubsection{Hasil Perhitungan Matriks Penghematan Jarak}

Menggabungkan 2 toko atau konsumen kedalam satu rute dengan cara (jarak dari gudang ke toko 1 dan dari toko 1 kembali ke gudang ditambah dengan jarak dari gudang ke toko 2 dan kemudian kembali ke gudang) - (jarak dari gudang ke toko 1 ditambah jarak dari toko 1 ke toko 2 ditambah jarak dari toko 2 ke gudang), dapat dirumuskan sebagai berikut: 2 Dist $(\mathrm{DC}, 1)+2$ Dist $(\mathrm{DC}, 2)-[$ Dist $(\mathrm{DC}, 1)+$ Dist $(1,2)+$ Dist $(2, \mathrm{DC})]=$ Dist $(\mathrm{DC}, 1)+$ Dist (DC,2) - Dist $(1,2)$

Contoh perhitungan adalah sebagai berikut:

- $\quad \mathrm{S}(102 \mathrm{SIM}, 103 \mathrm{BIJ})=$ Dist (NP, SIM) + Dist (NP, Blessing) - Dist (SIM, BIJ) S (102 SIM, 103 BIJ $)=$ Dist $(5,0)+$ Dist $(5,0)-$ Dist $(7,1)=2,93 \mathrm{~km}$

- $\mathrm{S}(103 \mathrm{BIJ}, 104 \mathrm{AWI})=\operatorname{Dist}(5,0)+\operatorname{Dis} \mathrm{t}(11,2)-\operatorname{Dist}(14,1)=2,04 \mathrm{~km}$

Berdasarkan perhitungan tersebut didapat bahwa jarak penghematan antara toko 102 SIM dan toko $103 \mathrm{BIJ}$ adalah sebesar 2,93 km, untuk toko 103 BIJ dan toko 104 AWI adalah sebesar 2,04 km. Perhitungan penghematan dilakukan menggunakan Microsoft Excell. Untuk perhitungan selengkapnya adalah sebagai berikut: 


\section{Tabel 4.6 Hasil Perhitungan Matriks Penghematan Jarak}

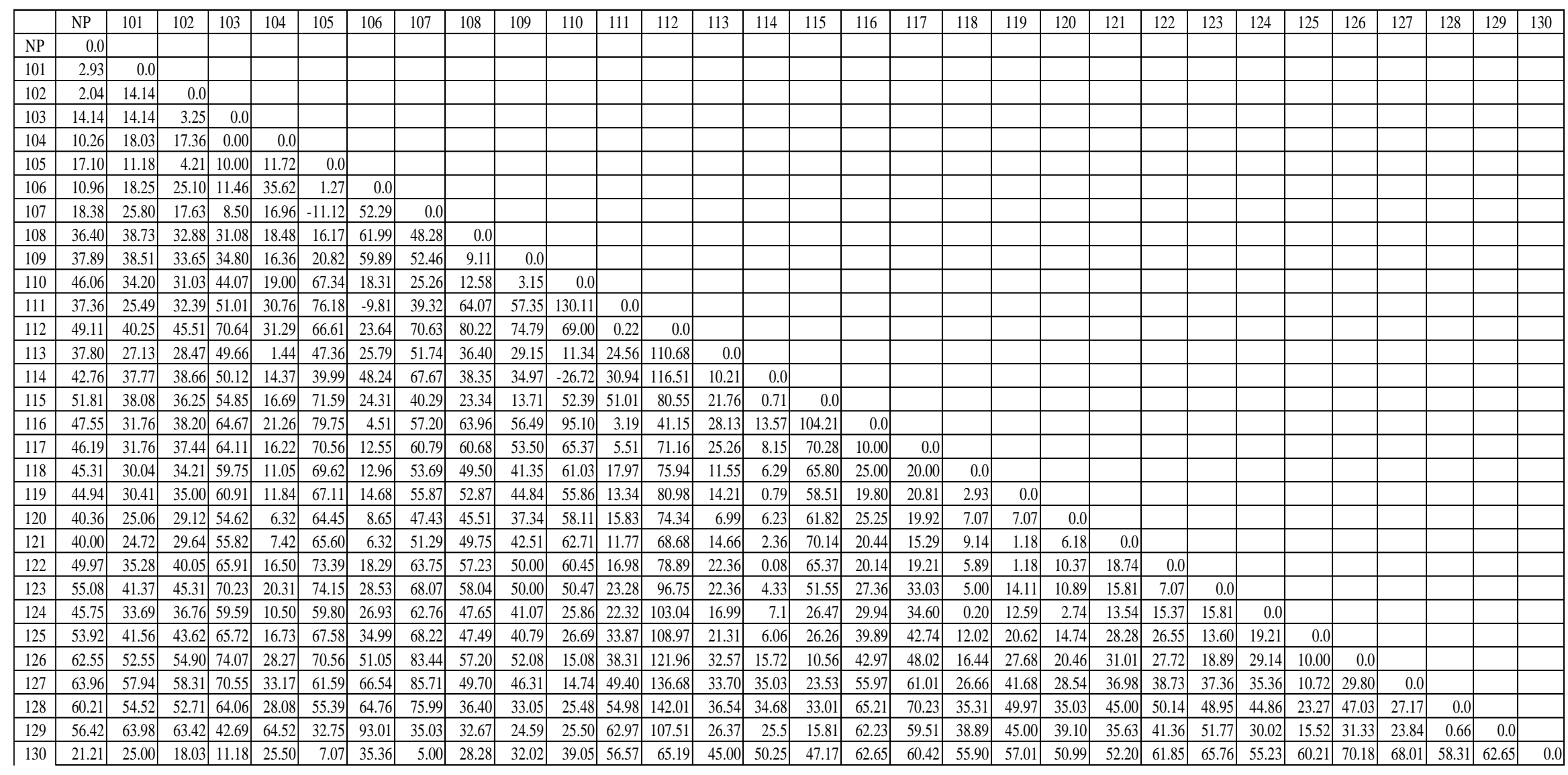

*Sumber: Data Diolah 


\subsubsection{Alokasi Rute Kendaraan.}

Tahap ini merupakan tahap akhir dari metode saving matrix. Tujuan dilakukannya penentuan kendaraan terhadap customer adalah untuk memaksimalkan penghematan jarak, untuk itu diperlukan prosedur iterasi yang akan dilakukan dari matriks penghematan. Syarat utamanya adalah dua rute digabung dalam satu rute jika total pengiriman kedua rute tidak melebihi kapasitas alat angkut yang dimiliki perusahaan. Didalam membuat alokasi diperlukan iterasi - iterasi.

Dari data matriks tersebut dapat diketahui bahwa:

1. Alokasi yang pertama sebesar $142,01 \mathrm{~km}$ yaitu rute 128 dengan rute 112 (128YB dengan 112GP), sehingga rute 28 digabung dengan rute 12, jumlah beban kedua toko adalah $17+4=21 \mathrm{~m}^{3}$.

2. Alokasi yang kedua sebesar $130,11 \mathrm{~km}$ yaitu rute 11 dengan rute 10 (111MI dengan 110L'E), sehingga rute 11 digabung dengan rute 10, jumlah beban kedua toko adalah $29+3=32 \mathrm{~m}^{3}$.

3. Alokasi yang ketiga sebesar $104,21 \mathrm{~km}$ yaitu rute 16 dengan rute 15 (116BKP dengan $115 \mathrm{GF}$ ), sehingga rute 16 digabung dengan rute 15 , jumlah beban kedua toko adalah $16+2=18 \mathrm{~m}^{3}$.

4. Alokasi yang keempat sebesar 93,01 km yaitu rute 29 dengan rute 6 (129SM dengan 106TU), sehingga rute 29 digabung dengan rute 6 , jumlah beban kedua toko adalah $9+5=14 \mathrm{~m}^{3}$.

5. Alokasi yang kelima sebesar $85,71 \mathrm{~km}$ yaitu rute 27 dengan rute 7 (127PDF dengan 107CMD), sehingga rute 27 digabung dengan rute 7 , jumlah beban kedua toko adalah $7+18=25 \mathrm{~m}^{3}$.

6. Alokasi yang keenam sebesar $80,22 \mathrm{~km}$ yaitu rute 8 dengan rute 12 (108SARI dengan $112 \mathrm{GP}$ ), namun karena rute 12 sudah terkonsolidasi dengan rute 1 , maka dilakukan penggabungan dengan menghitung jumlah beban antara $128 \mathrm{YB}, 112 \mathrm{GP}$, 108SARI yaitu $17+4+3=24 \mathrm{~m}^{3}$ (layak).

7. Alokasi yang ketujuh sebesar $74,15 \mathrm{~km}$ yaitu rute 23 dengan rute 5 (123SL dengan 105RI), sehingga rute 23 digabung dengan rute 5 , jumlah beban kedua toko adalah $2+7=9 \mathrm{~m}^{3}$.

8. Alokasi yang kedelapan sebesar 74,07 km yaitu rute 26 dengan rute 3 (126UL dengan 103AWI), sehingga rute 26 digabung dengan rute 3, jumlah beban kedua toko adalah $2+6=8 \mathrm{~m}^{3}$.

9. Alokasi yang kesembilan sebesar 45,00 km yaitu rute 30 dengan rute 13 (130ISP dengan $113 \mathrm{WI})$, sehngga rute 30 digabung dengan rute. Jumlah beban antar toko adalah $3+9=11 \mathrm{~m}^{3}$

10. Alokasi yang kesepuluh sebesar $35,62 \mathrm{~km}$ yaitu rute 6 dengan rute 4 (106TU dengan 104ICI), namun karena rute 6 sudah terhubung, maka dilakukan pencocokan dengan cara menggabungkan rute 4 dengan rute 6 dan rute 29 dengan jumlah beban $16+9+5=30 \mathrm{~m}^{3}$ (layak).

11. Alokasi yang kesebelas sebesar 53,50 km yaitu rute 9 dengan rute 17 (109GOC dengan 117CPI), sehingga rute 9 digabung dengan rute 17, jumlah beban kedua toko adalah $11+8=19 \mathrm{~m}^{3}$.

12. Alokasi yang keduabelas sebesar $42,74 \mathrm{~km}$ yaitu rute 25 dengan rute 17 (125NWS dengan $117 \mathrm{CPI}$ ), namun karena rute 17 sudah terhubung dengan rute 9, maka 
dilakukan penggabungan untuk rute 25 dengan rute 9 dan rute 17, jumlah beban antar toko adalah $11+8+6=25 \mathrm{~m}^{3}$ (layak)

\subsection{Mengurutkan Kunjungan Toko Pada Rute}

Pengurutan dilakukan dengan metode nearest insert dan nearest neighbour dengan tujuan mendapatkan jarak tempuh paling minimal dalam satu rute pengiriman.

\subsubsection{Pengurutan Dengan Metode Nearest Insert}

Prinsip metode nearest insert adalah memilih toko yang bila dimasukan kedalam rute yang sudah ada menghasilkan tambahan jarak yang minimum. Sebagai contoh adalah rute 22 Pada awalnya menetapkan rute dari gudang ke gudang dengan jarak nol, selanjutnya dapat dilihat hasil jarak yang diperoleh dengan menambahkan masing-masing toko ke rute yang sudah ada, sebagai berikut:

$$
\begin{aligned}
& \mathrm{NP} \text {-> } 122 \mathrm{LW}->\mathrm{NP}=100,9 \mathrm{~km} \\
& \mathrm{NP} \text {-> } 105 \mathrm{RI} \rightarrow>\mathrm{NP}=28,28 \mathrm{~km}
\end{aligned}
$$

Karena jarak yang paling minimum adalah $28,28 \mathrm{~km}$, maka yang dikunjungi lebih dulu adalah toko $105 \mathrm{RI}$, sehingga rute yang terbentuk adalah NP $\rightarrow 105 \mathrm{RI}$-> $122 \mathrm{LW}$-> NP dengan total jarak 14,14 +45,00 +55,90 = 115,04 km.

\section{Pengurutan Dengan Metode Nearest Neighbour}

Prinsip metode nearest neighbour adalah dengan menambahkan toko yang jaraknya paling dekat dengan toko yang dikunjungi terakhir. Pada awalnya dimulai dengan toko dengan jarak paling dekat dengan Distribution Center, contohnya pada rute 22 sebagai berikut:

Jarak yang terdekat dari DCNP antara toko 122 LW dan 105 RI adalah 45,00 km dan 14,14 $\mathrm{km}$, sehingga yang dikunjungi terlebih dahulu adalah toko yang terdekat yaitu 105 RI. Rute yang terbentuk adalah NP $\rightarrow 105 \mathrm{RI} \rightarrow 122 \mathrm{LW} \rightarrow \mathrm{NP}$ dengan total jarak 14,14 + 45,00 + 55,90 = $115,04 \mathrm{~km}$. Jarak yang dihasilkan antara metode nearest insert dan nerest neighbour pada rute 22 adalah sama yaitu sebesar 115,04 km.

Hasil dari perhitungan nearest insert dan nearest neighbour pada rute yang sudah terkonsolidasi dapat dilihat pada tabel 4.8 sebagai berikut:

\section{Tabel 4.8 Urutan kunjungan pada rute yang terkonsolidasi}

\begin{tabular}{|l|l|l|l|l|}
\hline Rute & Metode & Alokasi Toko & $\begin{array}{l}\text { Total } \\
\text { Jarak } \\
(\mathrm{km})\end{array}$ & $\begin{array}{l}\text { Total } \\
\text { Beban } \\
(\mathrm{m} 3)\end{array}$ \\
\hline 3 & Nearest Insert & NP $>>103$ AWI $->126$ UL $->$ NP & 130.53 & 8 \\
\hline
\end{tabular}




\begin{tabular}{|c|c|c|c|c|}
\hline Rute & Metode & Alokasi Toko & $\begin{array}{l}\text { Total } \\
\text { Jarak } \\
(\mathrm{km})\end{array}$ & $\begin{array}{l}\text { Total } \\
\text { Beban } \\
\text { (m3) }\end{array}$ \\
\hline & Nearest Neighbour & NP -> 103 AWI ->126 UL -> NP & 130.53 & \\
\hline \multirow[t]{2}{*}{9} & Nearest Insert & $\begin{array}{l}\text { NP }>>109 \text { GOC } \rightarrow 125 \text { NWS -> } \\
117 \text { CPU }>\text { NP }\end{array}$ & 211.37 & 25 \\
\hline & Nearest Neighbour & $\begin{array}{l}\text { NP } \rightarrow>109 \text { GOC } \rightarrow 125 \text { NWS }-> \\
117 \text { CPU }>>\text { NP }\end{array}$ & 211.37 & \\
\hline \multirow[t]{2}{*}{5} & Nearest Insert & NP $->105$ RI $->123$ SL $->$ NP & 124.6 & 9 \\
\hline & Nearest Neighbour & NP $->105$ RI $->123$ SL $->$ NP & 124.6 & \\
\hline \multirow[t]{2}{*}{4} & Nearest Insert & $\begin{array}{l}\text { NP }>104 \text { ICI }>106 \text { TU }>129 \\
\text { SM }>\text { NP }\end{array}$ & 171.14 & 14 \\
\hline & Nearest Neighbour & $\begin{array}{l}\text { NP }>104 \text { ICI }>106 \text { TU }>129 \\
\text { SM }>\text { NP }\end{array}$ & 171.14 & \\
\hline \multirow[t]{2}{*}{7} & Nearest Insert & NP -> 107 CMD -> 127 PDF -> NP & 142.31 & 25 \\
\hline & Nearest Neighbour & NP -> 107 CMD -> 127 PDF -> NP & 142.31 & \\
\hline \multirow[t]{2}{*}{8} & Nearest Insert & $\begin{array}{l}\text { NP -> } 108 \text { SARI -> } 112 \text { GP }->128 \\
\text { YB }->\text { NP }\end{array}$ & 299.88 & 24 \\
\hline & Nearest Neighbour & $\begin{array}{l}\text { NP -> } 108 \text { SARI -> } 112 \text { GP }->128 \\
\text { YB -> NP }\end{array}$ & 299.88 & \\
\hline \multirow[t]{2}{*}{10} & Nearest Insert & NP -> 110 L'E -> 111 MI -> NP & 145.84 & 32 \\
\hline & Nearest Neighbour & NP -> 110 L'E -> $111 \mathrm{MI}$-> NP & 145.84 & \\
\hline \multirow[t]{2}{*}{15} & Nearest Insert & NP -> 115 GF $>116$ BKP $->$ NP & 146.9 & 18 \\
\hline & Nearest Neighbour & NP $->115$ GF $->116$ BKP $->$ NP & 146.9 & \\
\hline \multirow[t]{2}{*}{13} & Nearest Insert & NP -> 113 WI $->130$ ISP $->$ NP & 99.75 & 9 \\
\hline & Nearest Neighbour & NP $>>113$ WI $>>130$ ISP $->$ NP & 99.75 & \\
\hline
\end{tabular}

*Sumber: Data Diolah

\subsubsection{Total Jarak dan Total Biaya Pengiriman}

Rute pengiriman setelah dilakukan alokasi toko ke kendaraan dan urutan kunjungan dengan metode nearest insert dan nearest neighbour kemudian dihitung total jarak dan total biaya kirim lalu dibandingkan dengan metode aktual pada perusahaan saat ini. BBM yang digunakan adalah premium dengan harga Rp5.150,- per liter, rasio konsumsi bbm adalah sebesar $1: 5$, yaitu dengan 1 liter bensin jarak yang mampu dicapai adalah $5 \mathrm{~km}$. Perhitungan selengkapnya adalah sebagai berikut:

\section{Total Jarak}

Tabel 4.9 Total jarak tempuh rute menggunakan saving matrix, nearest insert dan nearest neighbour 


\begin{tabular}{|c|c|c|c|c|}
\hline Rute & $\begin{array}{l}\text { Urutan } \\
\text { Pengiriman }\end{array}$ & Armada & Beban & $\begin{array}{l}\text { Jarak } \\
\text { Tempuh } \\
(\mathrm{km})\end{array}$ \\
\hline Rute 1 & 101 & L300 & 6 & 10 \\
\hline Rute 2 & 102 & L300 & 7 & 10 \\
\hline Rute 3 & $103->126$ & Fuso & 8 & 130.53 \\
\hline Rute 4 & $\begin{array}{l}104->106 \\
\rightarrow>129\end{array}$ & Fuso & 30 & 148.7 \\
\hline Rute 5 & $105->123$ & L300 & 9 & 124.6 \\
\hline Rute 6 & $113->130$ & L300 & 12 & 99.75 \\
\hline Rute 7 & 107 -> 127 & Fuso & 25 & 140.49 \\
\hline Rute 8 & $\begin{array}{l}108->112 \\
->128\end{array}$ & Fuso & 24 & 137.09 \\
\hline Rute 9 & $\begin{array}{l}109 \rightarrow 125 \\
\rightarrow>117\end{array}$ & Fuso & 25 & 146.1 \\
\hline $\begin{array}{l}\text { Rute } \\
10\end{array}$ & 110 -> 111 & Fuso & 32 & 145.84 \\
\hline $\begin{array}{l}\text { Rute } \\
11\end{array}$ & 114 & L300 & 6 & 80.62 \\
\hline $\begin{array}{l}\text { Rute } \\
12\end{array}$ & 118 & L300 & 6 & 80.62 \\
\hline $\begin{array}{l}\text { Rute } \\
13\end{array}$ & 119 & L300 & 12 & 80 \\
\hline $\begin{array}{l}\text { Rute } \\
14\end{array}$ & 120 & L300 & 2 & 70.71 \\
\hline $\begin{array}{l}\text { Rute } \\
15\end{array}$ & $115->116$ & Fuso & 18 & 132.61 \\
\hline $\begin{array}{l}\text { Rute } \\
16\end{array}$ & 121 & Fuso & 13 & 70 \\
\hline $\begin{array}{l}\text { Rute } \\
17\end{array}$ & 122 & L300 & 2 & 90 \\
\hline $\begin{array}{l}\text { Rute } \\
18\end{array}$ & 124 & Fuso & 16 & 82.46 \\
\hline \multicolumn{3}{|l|}{ Jumlah } & 253 & 1780.12 \\
\hline
\end{tabular}

*Sumber: Data Diolah

Berdasarkan tabel diatas dapat dilihat total jarak tempuh pada pengiriman pagi perhitungan saving matrix, nearest insert dan nearest adalah $1780,12 \mathrm{~km}$ dengan jumlah rute sebanyak 18 . Sedangkan untuk rute atau jarak yang dilalui pada saat ini dapat dilihat pada tabel 4.10, yaitu sebagai berikut: 
Tabel 4.10 Total jarak tempuh rute pada saat ini

\begin{tabular}{|c|c|c|c|c|c|c|c|c|}
\hline \multicolumn{5}{|l|}{ Rute } & $\begin{array}{l}\text { Urutan } \\
\text { Pengirim } \\
\text { an }\end{array}$ & $\begin{array}{l}\text { Arma } \\
\text { da }\end{array}$ & $\begin{array}{l}\text { Beb } \\
\text { an }\end{array}$ & $\begin{array}{l}\text { Jarak } \\
\text { Tempuh } \\
(\mathrm{km})\end{array}$ \\
\hline \multicolumn{5}{|l|}{ Rute 1} & 101 & L300 & 6 & 10 \\
\hline \multicolumn{5}{|l|}{ Rute 2} & 102 & L300 & 7 & 10 \\
\hline \multicolumn{5}{|l|}{ Rute 3} & $\begin{array}{ll}103 & -> \\
115 & \end{array}$ & L300 & 5 & 105.52 \\
\hline \multicolumn{5}{|l|}{ Rute 4} & 104 & Fuso & 16 & 28.28 \\
\hline \multicolumn{5}{|l|}{ Rute 5} & $\begin{array}{ll}105 & \rightarrow \\
122 & \end{array}$ & L300 & 9 & 115.04 \\
\hline \multicolumn{5}{|l|}{ Rute 6} & 106 & L300 & 5 & 28.28 \\
\hline \multicolumn{5}{|l|}{ Rute 7} & 107 & Fuso & 18 & 36.06 \\
\hline \multicolumn{5}{|l|}{ Rute 8} & $\begin{array}{ll}108 & -> \\
120 & \end{array}$ & L300 & 5 & 113.14 \\
\hline \multicolumn{5}{|l|}{ Rute 9} & 109 & Fuso & 11 & 72.8 \\
\hline \multicolumn{5}{|l|}{ Rute 10} & 111 & Fuso & 29 & 70.71 \\
\hline \multicolumn{5}{|l|}{ Rute 11} & 112 & L300 & 4 & 89.44 \\
\hline \multicolumn{5}{|l|}{ Rute 12} & 113 & L302 & 9 & 67.08 \\
\hline \multicolumn{5}{|l|}{ Rute 13} & 114 & L300 & 6 & 80.62 \\
\hline \multicolumn{5}{|l|}{ Rute 14} & 116 & Fuso & 16 & 85.44 \\
\hline \multicolumn{5}{|l|}{ Rute 15} & 117 & L300 & 8 & 82.46 \\
\hline \multicolumn{5}{|l|}{ Rute 16} & 118 & L300 & 6 & 80.62 \\
\hline \multicolumn{5}{|l|}{ Rute 17} & 119 & Fuso & 12 & 80 \\
\hline \multicolumn{5}{|l|}{ Rute 18} & 121 & Fuso & 13 & 70 \\
\hline \multicolumn{5}{|l|}{ Rute 19} & $\begin{array}{ll}123 & -> \\
110 & \end{array}$ & L300 & 4 & 143.32 \\
\hline \multicolumn{5}{|l|}{ Rute 20} & 124 & Fuso & 16 & 82.46 \\
\hline \multicolumn{5}{|l|}{ Rute 21} & 125 & L300 & 6 & 98.49 \\
\hline \multicolumn{5}{|l|}{ Rute 22} & 126 & L300 & 6 & 117.05 \\
\hline \multicolumn{5}{|l|}{ Rute 23} & 127 & L300 & 7 & 122.07 \\
\hline \multicolumn{5}{|l|}{ Rute 24} & 128 & Fuso & 17 & 114.02 \\
\hline Rute 25 & $\begin{array}{ll}129 & -> \\
130 & \end{array}$ & L300 & 12 & 144.07 & & & & \\
\hline \multicolumn{3}{|l|}{ Jumlah } & 253 & 2046.97 & & & & \\
\hline
\end{tabular}

*Sumber: Data Diolah

Berdasarkan tabel diatas dapat dilihat total jarak tempuh pengiriman rute aktual saat ini adalah 2046,97 km dengan jumlah rute sebanyak 25 . 


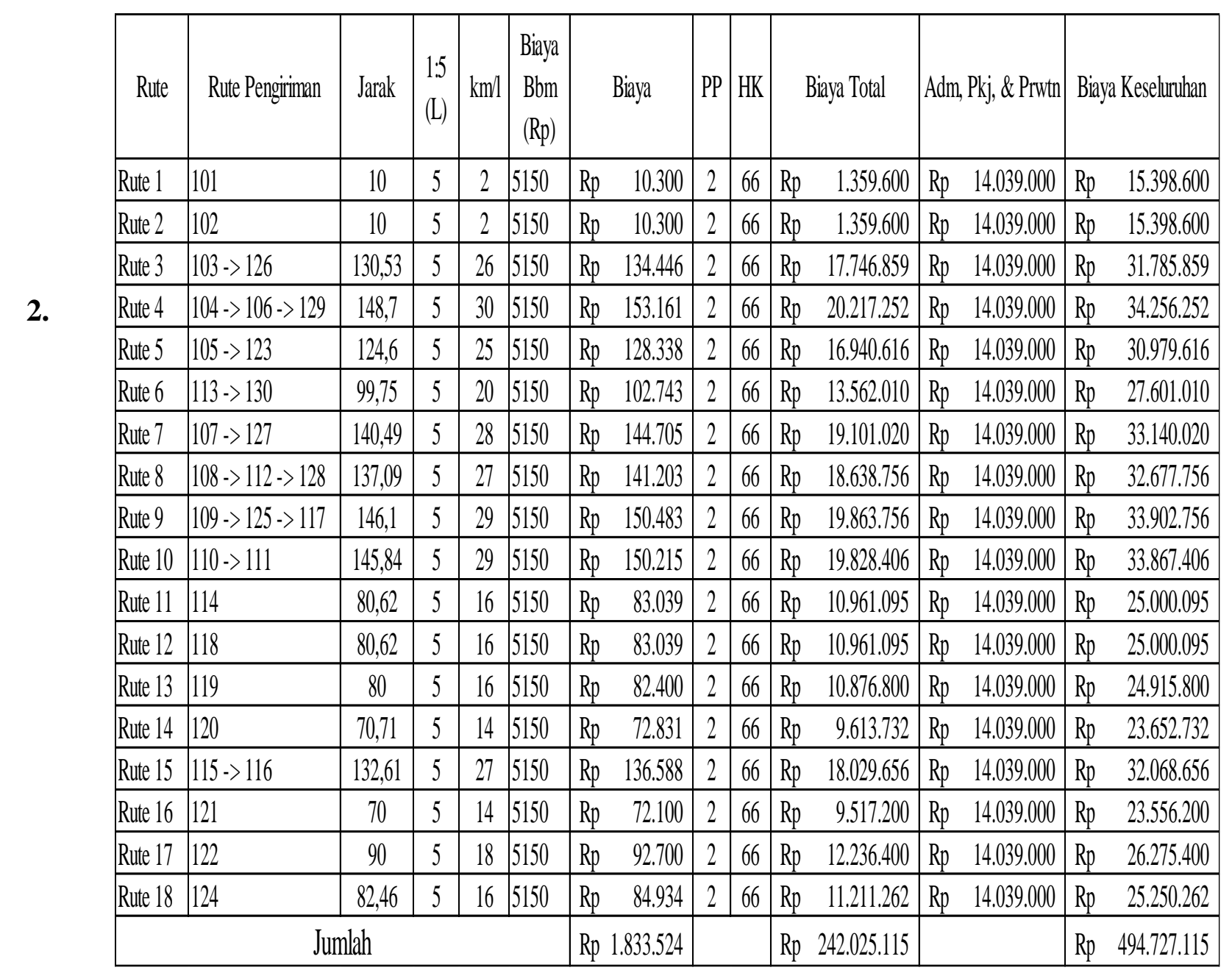

\section{Total Biaya Kirim}

Tabel 4.11 Total biaya kirim rute menggunakan saving matrix, nearest insert, dan nearest neighbour.

*Sumber: Data Diolah

Berdasarkan table diatas dapat dilihat total biaya pada pengiriman rute dengan perhitungan saving matrix, nearest insert dan nearest neighbor adalah sebesar Rp. 494.727.115,-- 
COMPETITIVE, Vol.13. No.1 Desember 2018

ISSN : 0216-2539

\begin{tabular}{|c|c|c|c|c|c|c|c|c|c|c|c|c|c|c|c|c|}
\hline \multirow{5}{*}{$\begin{array}{l}\text { Tabel } \\
4.12 \\
\text { Total } \\
\text { Biaya }\end{array}$} & \multirow{2}{*}{\begin{tabular}{|c|} 
Rute \\
Rute 1 \\
\end{tabular}} & \multirow{2}{*}{\begin{tabular}{|l} 
Rute Pengiriman \\
101 \\
\end{tabular}} & \multirow{2}{*}{$\begin{array}{c}\text { Jarak } \\
10 \\
\end{array}$} & \multirow{2}{*}{\begin{tabular}{|l|}
$1: 5$ \\
$(\mathrm{~L})$ \\
5 \\
\end{tabular}} & \multirow{2}{*}{\begin{tabular}{r|}
$\mathrm{km} / \mathrm{l}$ \\
2 \\
\end{tabular}} & \multirow{2}{*}{$\begin{array}{l}\text { Biaya } \\
\text { Bbm } \\
5150 \\
\end{array}$} & \multicolumn{2}{|r|}{ Biaya } & pp & HK & \multicolumn{2}{|c|}{ Biaya Total } & \multicolumn{2}{|c|}{ Adm, Pkj, \& Prwtn } & \multicolumn{2}{|c|}{ Biaya Keseluruhan } \\
\hline & & & & & & & $\mathrm{Rp}$ & 10.300 & 2 & 66 & $\mathrm{Rp}$ & 1.359 .600 & $\mathrm{Rp}$ & 14.039 .000 & $\mathrm{Rp}$ & 15.398 .600 \\
\hline & Rute 2 & 102 & 10 & 5 & 2 & 5150 & $\mathrm{Rp}$ & 10.300 & 2 & 66 & $\mathrm{Rp}$ & 1.359 .600 & $\mathrm{Rp}$ & 14.039 .000 & $\mathrm{Rp}$ & 15.398 .600 \\
\hline & Rute 3 & 103 -> 115 & 105,52 & 5 & 21 & 5150 & $\mathrm{Rp}$ & 108.686 & 2 & 66 & $\mathrm{Rp}$ & 14.346 .499 & $\mathrm{Rp}$ & 14.039 .000 & $\mathrm{Rp}$ & 28.385 .499 \\
\hline & Rute 4 & 104 & 28,28 & 5 & 6 & 5150 & $\mathrm{Rp}$ & 29.128 & 2 & 66 & $\mathrm{Rp}$ & 3.844 .949 & $\mathrm{Rp}$ & 14.039 .000 & $\mathrm{Rp}$ & 17.883 .949 \\
\hline & Rute 5 & 105 -> 122 & 115,04 & 5 & 23 & 5150 & $\mathrm{Rp}$ & 118.491 & 2 & 66 & $\mathrm{Rp}$ & 15.640 .838 & $\mathrm{Rp}$ & 14.039 .000 & $\mathrm{Rp}$ & 29.679 .838 \\
\hline & Rute 6 & 106 & 28,28 & 5 & 6 & 5150 & $\mathrm{Rp}$ & 29.128 & 2 & 66 & Rp & 3.844 .949 & $\mathrm{Rp}$ & 14.039 .000 & $\mathrm{Rp}$ & 17.883 .949 \\
\hline & Rute 7 & 107 & 36,06 & 5 & 7 & 5150 & $\mathrm{Rp}$ & 37.142 & 2 & 66 & $\mathrm{Rp}$ & 4.902 .718 & $\mathrm{Rp}$ & 14.039 .000 & $\mathrm{Rp}$ & 18.941 .718 \\
\hline & Rute 8 & 108 -> 120 & 113,14 & 5 & 23 & 5150 & $\mathrm{Rp}$ & 116.534 & 2 & 66 & $\mathrm{Rp}$ & 15.382 .514 & $\mathrm{Rp}$ & 14.039 .000 & $\mathrm{Rp}$ & 29.421 .514 \\
\hline & Rute 9 & 109 & 72,8 & 5 & 15 & 5150 & $\mathrm{Rp}$ & 74.984 & 2 & 66 & $\mathrm{Rp}$ & 9.897 .888 & $\mathrm{Rp}$ & 14.039 .000 & $\mathrm{Rp}$ & 23.936 .888 \\
\hline & Rute 10 & 111 & 70,71 & 5 & 14 & 5150 & $\mathrm{Rp}$ & 72.831 & 2 & 66 & $\mathrm{Rp}$ & 9.613 .732 & $\mathrm{Rp}$ & 14.039 .000 & $\mathrm{Rp}$ & 23.652 .732 \\
\hline & \begin{tabular}{|l|} 
Rute 11 \\
\end{tabular} & 112 & 89,44 & 5 & 18 & 5150 & $\mathrm{Rp}$ & 92.123 & 2 & 66 & $\mathrm{Rp}$ & 12.160 .262 & $\mathrm{Rp}$ & 14.039 .000 & $\mathrm{Rp}$ & 26.199 .262 \\
\hline & Rute 12 & 113 & 67,08 & 5 & 13 & 5150 & $\mathrm{Rp}$ & 69.092 & 2 & 66 & $\mathrm{Rp}$ & 9.120 .197 & $\mathrm{Rp}$ & 14.039 .000 & $\mathrm{Rp}$ & 23.159 .197 \\
\hline & \begin{tabular}{|l|} 
Rute 13 \\
\end{tabular} & 114 & 80,62 & 5 & 16 & 5150 & $\mathrm{Rp}$ & 83.039 & 2 & 66 & $\mathrm{Rp}$ & 10.961 .095 & $\mathrm{Rp}$ & 14.039 .000 & $\mathrm{Rp}$ & 25.000 .095 \\
\hline & Rute 14 & 116 & 85,44 & 5 & 17 & 5150 & $\mathrm{Rp}$ & 88.003 & 2 & 66 & $\mathrm{Rp}$ & 11.616 .422 & $\mathrm{Rp}$ & 14.039 .000 & $\mathrm{Rp}$ & 25.655 .422 \\
\hline & \begin{tabular}{|l|} 
Rute 15 \\
\end{tabular} & 117 & 82,46 & 5 & 16 & 5150 & $\mathrm{Rp}$ & 84.934 & 2 & 66 & $\mathrm{Rp}$ & 11.211 .262 & $\mathrm{Rp}$ & 14.039 .000 & $\mathrm{Rp}$ & 25.250 .262 \\
\hline & Rute 16 & 118 & 80,62 & 5 & 16 & 5150 & $\mathrm{Rp}$ & 83.039 & 2 & 66 & $\mathrm{Rp}$ & 10.961 .095 & $\mathrm{Rp}$ & 14.039 .000 & $\mathrm{Rp}$ & 25.000 .095 \\
\hline & \begin{tabular}{|l|} 
Rute 17 \\
\end{tabular} & 119 & 80 & 5 & 16 & 5150 & $\mathrm{Rp}$ & 82.400 & 2 & 66 & $\mathrm{Rp}$ & 10.876 .800 & $\mathrm{Rp}$ & 14.039 .000 & $\mathrm{Rp}$ & 24.915 .800 \\
\hline & Rute 18 & 121 & 70 & 5 & 14 & 5150 & $\mathrm{Rp}$ & 72.100 & 2 & 66 & $\mathrm{Rp}$ & 9.517 .200 & $\mathrm{Rp}$ & 14.039 .000 & $\mathrm{Rp}$ & 23.556 .200 \\
\hline & \begin{tabular}{|l|} 
Rute 19 \\
\end{tabular} & 123 -> 110 & 143,32 & 5 & 29 & 5150 & $\mathrm{Rp}$ & 147.620 & 2 & 66 & $\mathrm{Rp}$ & 19.485 .787 & $\mathrm{Rp}$ & 14.039 .000 & $\mathrm{Rp}$ & 33.524 .787 \\
\hline & Rute 20 & 124 & 82,46 & 5 & 16 & 5150 & $\mathrm{Rp}$ & 84.934 & 2 & 66 & $\mathrm{Rp}$ & 11.211 .262 & $\mathrm{Rp}$ & 14.039 .000 & $\mathrm{Rp}$ & 25.250 .262 \\
\hline & \begin{tabular}{|l|} 
Rute 21 \\
\end{tabular} & 125 & 98,49 & 5 & 20 & 5150 & $\mathrm{Rp}$ & 101.445 & 2 & 66 & $\mathrm{Rp}$ & 13.390 .700 & $\mathrm{Rp}$ & 14.039 .000 & $\mathrm{Rp}$ & 27.429 .700 \\
\hline & Rute 22 & 126 & 117,05 & 5 & 23 & 5150 & $\mathrm{Rp}$ & 120.562 & 2 & 66 & $\mathrm{Rp}$ & 15.914 .118 & $\mathrm{Rp}$ & 14.039 .000 & $\mathrm{Rp}$ & 29.953 .118 \\
\hline & Rute 23 & 127 & 122,07 & 5 & 24 & 5150 & $\mathrm{Rp}$ & 125.732 & 2 & 66 & $\mathrm{Rp}$ & 16.596 .637 & $\mathrm{Rp}$ & 14.039 .000 & $\mathrm{Rp}$ & 30.635 .637 \\
\hline & Rute 24 & 128 & 114,02 & 5 & 23 & 5150 & $\mathrm{Rp}$ & 117.441 & 2 & 66 & $\mathrm{Rp}$ & 15.502 .159 & $\mathrm{Rp}$ & 14.039 .000 & $\mathrm{Rp}$ & 29.541 .159 \\
\hline & Rute 25 & 129 -> 130 & 144,07 & 5 & 29 & 5150 & $\mathrm{Rp}$ & 148.392 & 2 & 66 & $\mathrm{Rp}$ & 19.587 .757 & $\mathrm{Rp}$ & 14.039 .000 & $\mathrm{Rp}$ & 33.626 .757 \\
\hline & \multicolumn{6}{|c|}{ Jumlah } & $\mathrm{Rp}$ & 2.108 .379 & & & $\mathrm{Rp}$ & 278.306 .041 & & & $\mathrm{Rp}$ & 629.281 .041 \\
\hline
\end{tabular}

\section{Pengiriman Rute Pada Saat Ini Oleh Perusahaan}

*Sumber: Data Diolah

Berdasarkan tabel diatas dapat dilihat total biaya pengiriman rute aktual pada perusahaan saat ini adalah sebesar Rp 629.281.041,-.

\subsubsection{Menghitung Penghematan Jarak Dan Biaya}

Total perbandingan penghematan jarak dan biaya setelah dilakukan penelitian yang dihasilkan antara metode aktual perusahaan dengan metode saving matrix adalah sebagai berikut:

Tabel 4.13 Hasil Penghematan Jarak Dan Biaya

\begin{tabular}{|l|l|l|l|l|l|}
\hline No. & Parameter & Awal & Usulan & Selisih & Persentase \\
\hline
\end{tabular}




\begin{tabular}{|l|l|l|l|l|l|}
\hline 1 & $\begin{array}{l}\text { Total } \\
\text { Jarak } \\
(\mathrm{km})\end{array}$ & 2046.97 & 1780.12 & 266.85 & $13.03 \%$ \\
\hline 2 & $\begin{array}{l}\text { Total } \\
\text { Biaya }\end{array}$ & $\begin{array}{l}\mathrm{Rp} \\
629,281,041\end{array}$ & $\begin{array}{c}\mathrm{Rp} \\
494,727,115\end{array}$ & $\begin{array}{l}\mathrm{Rp} \\
134,553,926\end{array}$ & $21.38 \%$ \\
\hline
\end{tabular}

\section{KESIMPULAN}

Berdasarkan hasil perhitungan yang diperoleh bahwa terdapat perbedaan rute antara perhitUngan metode saving matrix, nearest insert dan nearest neighbour dengan rute aktual yang ada pada perusahaan, rute hasil perhitungan saving matrix, nearest insert dan nearest neighbour adalah sebagai berikut:

\begin{tabular}{|c|c|c|}
\hline Rute $1=101$ & Rute $7=107-127$ & Rute $13=119$ \\
\hline Rute $2=102$ & Rute $8=108-112-128$ & Rute $14=120$ \\
\hline Rute $3=103-126$ & Rute $9=109-125-117$ & Rute $15=115-116$ \\
\hline Rute $4=104-106-129$ & Rute $10=110-111$ & Rute $16=121$ \\
\hline Rute $5=105-123$ & Rute $11=114$ & Rute $17=122$ \\
\hline Rute $6=113-130$ & Rute $12=118$ & Rute $18=124$ \\
\hline
\end{tabular}

Sedangkan hasil perhitungan rute aktual pada perusahaan adalah sebagai berikut:

\begin{tabular}{|c|c|c|c|}
\hline Rute $1=101$ & Rute $7=107$ & Rute $13=113$ & Rute $19=121$ \\
\hline Rute $2=102$ & Rute $8=108-120$ & Rute $14=114$ & Rute $20=124$ \\
\hline Rute $3=103-115$ & Rute $9=109$ & Rute $15=116$ & Rute $21=125$ \\
\hline Rute $4=104$ & Rute $10=110-123$ & Rute $16=117$ & Rute $22=126$ \\
\hline Rute $5=105-122$ & Rute $11=111$ & Rute $17=118$ & Rute $23=127$ \\
\hline Rute $6=106$ & Rute $12=112$ & Rute $18=119$ & Rute $24=128$ \\
\hline
\end{tabular}

Rute $25=129-130$

Hasil perhitungan alokasi saving matrix membentuk rute konsolidasi sebagai berikut:

\begin{tabular}{|c|c|c|}
\hline Rute 3 & $=$ & NP $>>103$ AWI $->126$ UL $->$ NP \\
\hline Rute 4 & $=$ & NP $->104 \mathrm{ICI}$-> $106 \mathrm{TU}$-> $129 \mathrm{SM}$-> NP \\
\hline Rute 5 & $=$ & $\mathrm{NP}->105 \mathrm{RI} \rightarrow>123 \mathrm{SL} \rightarrow>\mathrm{NP}$ \\
\hline Rute 7 & $=$ & NP $->107$ CMD $->127$ PDF $->$ NP \\
\hline Rute 8 & $=$ & NP $\rightarrow>108$ SARI $->112$ GP $\rightarrow>128 \mathrm{YB}$-> NP \\
\hline
\end{tabular}




\begin{tabular}{lll}
\hline Rute 9 & $=$ & $\mathrm{NP} \rightarrow>109 \mathrm{GOC} \rightarrow>125 \mathrm{NWS} \rightarrow>117 \mathrm{CPU} \rightarrow \mathrm{NP}$ \\
Rute 10 & $=$ & $\mathrm{NP} \rightarrow>110 \mathrm{~L}^{\prime} \mathrm{E} \rightarrow>111 \mathrm{MI} \rightarrow \mathrm{NP}$ \\
Rute 13 & $=$ & $\mathrm{NP} \rightarrow 115 \mathrm{GF} \rightarrow 116 \mathrm{BKP} \rightarrow \mathrm{NP}$ \\
Rute 15 & $=$ & $\mathrm{NP} \rightarrow>113 \mathrm{WI} \rightarrow>130 \mathrm{ISP} \rightarrow>\mathrm{NP}$
\end{tabular}

Perhitungan urutan kunjungan customer pada rute yang sudah dikonsolidasikan dengan metode neareset insert dan nearest neighbour menghasilkan total jarak yang sama pada setiap rute.Rute yang terbentuk dengan metode penelitian pada penelitian ini berjumlah 18 rute. Sedangkan rute aktual pada perusahaan berjumlah 25 rute, sehingga diperoleh pernghematan jumlah rute sebanyak 7 rute. Total jarak yang dihasilkan melalui metode perhitunan saving matrix, nearest insert dan nearest neighbour adalah sebesar 1700,69 km. Sedangkan total jarak pengiriman rute aktual pada perusahaan adalah sebesar 2046,97 km. Penghematan antara rute penelitian ini dengan rute aktual perusahaan adalah sebesar $346,28 \mathrm{~km}$.

Total biaya pengiriman/transportasi yang dihasilkan melalui metode perhitungan saving matrix, nearest insert dan nearest neighbour adalah sebesar Rp. 483.927.812,-. Sedangkan total biaya pengiriman/transportasi rute aktual pada perusahaan adalah sebesar Rp. 629.281.041,-Penghematan total biaya transportasi/pengiriman antara metode penelitian saving matrix dengan total biaya perusahaan adalah sebesar Rp. 145.353.229 atau 23,09\%.

\section{DAFTAR PUSTAKA}

Dharmmesta, B. S. (2014). Manajemen pemasaran.

Geraldin, L. H., Pujawan, I. N., \& Dewi, D. S. (2007). Manajemen risiko dan aksi mitigasi untuk menciptakan rantai pasok yang robust. Jurnal Teknologi dan Rekayasa Teknik Sipil (TORSI), 2007, 53-64.

Purnomo, A. (2010). Penentuan rute pengiriman dan biaya transportasi dengan menggunakan Metode Clark and Wright Saving Heuristic (Studi kasus PT The Botol Sosro Bandung) J. Logistik Politeknik Pos Indonesia, 1, 97-117.

Rahmawati, R., Matondang, N., \& Sari, R. M. (2014). Usulan Model dalam Menentukan Rute Distribusi untuk Meminimalkan Biaya Transportasi dengan Metode Saving Matrix di PT. Xyz. Jurnal Teknik Industri USU, 5(2).

Tjiptono, F., Chandra, G., \& Adriana, D. (2008). Pemasaran strategik. Yogyakarta: Andi.

Vanany, I., Zailani, S., \& Pujawan, N. (2009). Supply chain risk management: literature review and future research. International Journal of Information Systems and Supply Chain Management (IJISSCM), 2(1), 16-33.

Wook Kim, S. (2006). Effects of supply chain management practices, integration and competition capability on performance. Supply Chain Management: An International Journal, 11(3), 241-248.

Yuniarti, R., \& Astuti, M. (2013). Penerapan Metode Saving Matrix Dalam Penjadwalan Dan Penentuan Rute Distribusi Premium Di SPBU Kota Malang. Rekayasa Mesin, 4(1), 17-26. 